\title{
Implementasi Teknologi Energi Surya Sebagai Wujud Mandiri Energi Listrik Di Masjid Al-Falah Serua Ciputat Tangerang Selatan
}

\author{
Christine Widyastuti $^{1}$; Oktaria Handayani ${ }^{2}$; Tony Koerniawan ${ }^{3}$ \\ ${ }^{1,2,3}$ Fakultas Ketenagalistrikan dan Energi Terbarukan, Institut Teknologi PLN \\ ${ }^{1}$ christine.widyastuti@itpln.ac.id
}

\begin{abstract}
The existence of street lighting and or public facilities is one of the things that is very important for the smooth running of residents' activities, especially at night. However, not all of them had lighting installed as in the Al-Falah Serua Ciputat Mosque in South Tangerang. This village is a village that is electrified but electricity supply for public facilities and roads is still minimal, due also to the large cost of using electricity. Therefore it is necessary to install public and street lighting facilities in this case in the form of solar lights as an effective alternative to solutions in lighting and to reduce the cost of using electricity from PLN. The solar lights are very suitable to be installed in this location, considering that the lights do not require electricity from residents' houses and PLN, and geographically the location is very potential for utilizing solar power because it is still very green. Solar lights are installed at strategic points on the road to Al Falah Mosque and the front porch of Al Falah Mosque itself. The lamp used is a HILIOS SL-40W lamp with 40 Watt power. In addition to street lighting and public facilities, an economic analysis is also carried out on this activity by comparing the total costs required between incandescent lighting with solar power. Where the nominal difference obtained in rupiah is Rp 311,055.2 lighter than PJU incandescent lamps, and solar lights are not affected by TDL (basic electricity tariff).
\end{abstract}

Keywords: Roads, Public Facilities, Lights, Solar Energy

\begin{abstract}
ABSTRAK
Keberadaan penerangan jalan dan atau fasilitas umum adalah salah satu hal yang sangat penting demi kelancaran aktivitas warga khususnya di malam hari. Tetapi, tidak semuanya telah terpasang penerangan seperti halnya di Masjid Al-Falah Serua Ciputat Tangerang Selatan. Desa ini merupakan desa yang teraliri arus listrik namun pasokan listrik untuk fasilitas umum dan jalan masih minim, dikarenakan pula oleh besarnya biaya pemakaian energi listrik. Oleh karena itu diperlukan pemasangan penerangan fasilitas umum dan jalan dalam hal ini berupa lampu tenaga surya sebagai alternatif efektif untuk solusi dalam penerangan dan pengurangan biaya pemakaian energi listrik dari PLN. Lampu tenaga surya sangat sesuai umtuk dipasang di lokasi ini mengingat lampu tersebut tidak memerlukan pasokan listrik dari rumah warga dan PLN serta secara keadaan geografis lokasi ini sangat potensial untuk memanfaatkan tenaga surya dikarenakan masih sangat terbuka hijau. Lampu tenaga surya di pasang di titik strategis yaitu di jalan menuju Masjid Al Falah dan depan teras Masjid Al Falah itu sendiri. Lampu yang digunakan adalah lampu HILIOS SL-40W dengan daya 40 Watt. Selain untuk penerangan jalan dan fasilitas umum, analisis ekonomi juga dilakukan pada kegiatan ini dengan cara membandingkan total biaya yang diperlukan antara penerangan lampu pijar dengan tenaga surya. Dimana didapat selisih nominal dalam rupiah $R p$ 311.055,2 lebih ringan dari PJU lampu pijar, dan lampu tenaga surya tidak dipengaruhi oleh TDL (tarif dasar listrik).
\end{abstract}

Kata Kunci: Jalan, Fasilitas Umum, Lampu, Tenaga Surya 


\section{PENDAHULUAN}

Setiap tahunnya kebutuhan energi listrik semakin meningkat. Di Indosnesia sendiri, proyeksi kebutuhan listrik mencapai 6,86\% setiap tahunnya ( RUPTL PLN 3018 ). Naiknya kebutuhan listrik dapat diartikan sebagai naiknya kebutuhan akan minyak dan gas bumi sebagai bahan bakar utama pembagnkit listrik yang ada di Indonesia. Padahal minyak dan gas bumi yang berasal dari fossil yang jumlahnya terbatas dan memiliki efek samping. Apabila dalam waktu dekat tidak dikembangkan sumber-sumber energi listrik baru yang signifikan maka pada tahun 3046 dikhwatirkan Indonesia akan mengalami defisit energi [2].

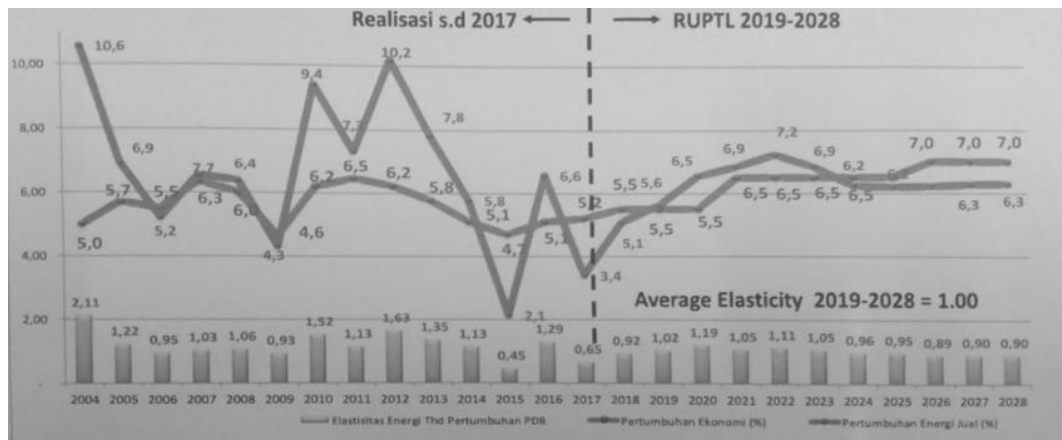

Gambar 1. Elastisits Pertumbuhan Kebutuhan Listrik Terhadap Pertumbuhan Ekonomi[5]

PT.PLN Persero telah melakukan berbagai upaya untuk dapat mengatasi peningkatan kebutuhan energi listrik dan menambah rasio elektrifikasi di daerah ini, khususnya di Tangerang Selatan. PT PLN ( Persero ) menilai kebutuhan penambahan daya listrik di bagian Serua Ciputat ini cukup mendesak mengingat pertumbuhan daerah pemukiman yang semakin meningkat. Namun pertumbuhan pemukiman tidak dibarengi dengan pasokan energi listrik, dan kurangnya ilmu pengetahuan dan teknologi di daerah ini akan sumber-sumber energi listrik baru yang ramah lingkungan, serta masih banyaknya warga masyarakat yang memanfaatkan energi listrik untuk penerangan jalan dengan cara cantol ( ilegal ) dari hal ini tentu akan membawa dampak negatif baik bagi masyarakat maupun bagi pihak pemasok daya listrik dalam hal ini adalah PT.PLN ( Persero ). Dalam hal ini pasokan energi listrik yang ramah lingkungan dipilihlah pemanfaatan energi surya, selain dari ramah lingkungan juga dari segi ketersediaan di alam tentunya akan terus menerus dan tidak ada habisnya ( renewable energy ). Karena matahari adalah sumber energi utama yang memancarkan energi yang luar biasa besarnya ke permukaan bumi.

Diharapkan dengan semakin meningkatnya pemanfaatan energi surya sebagai sumber energi listrik lain yang terbarukan. Sehingga dapat mendukung target capaian EBT pada tahun 3025 sebesar 23\% ( RUPTL 3019-3028).

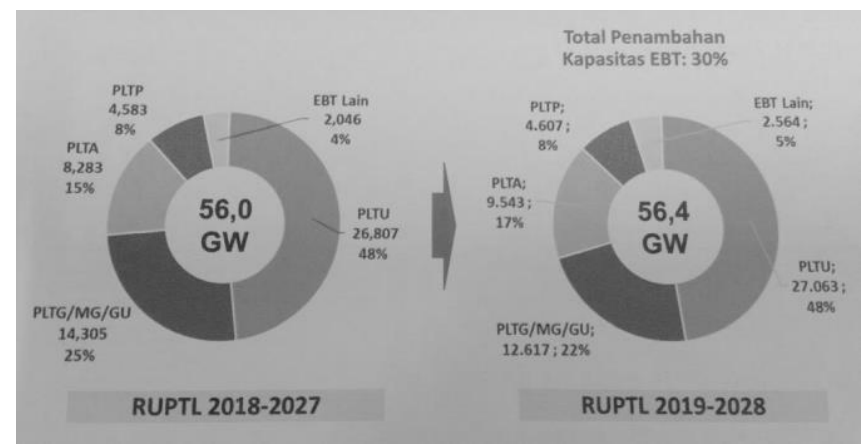

Gambar 2. Perbandingan Kapasitas Pembangkit 
Untuk wilayah Indonesia, berdasarkan data penyinaran matahari yang dihimpun dari 18 lokasi yang berbeda, radiasi surya di Indonesia dapat diklasifikasikan berturut-turut sebagai berikut : kawasan barat Indonesia sekitar 4,5 kWh/m2/hari dengan variasi bulanan sekitar 10\% dan kawasan timur Indonesia sekitar $5,1 \mathrm{kWh} / \mathrm{m} 2 /$ hari dengan variasi bulanan sekitar $9 \%$. dengan demikian potensi penyinaran matahari rata-rata di Indonesia sekitar $4,8 \% / \mathrm{kWh} / \mathrm{m} 2 / \mathrm{hari}$ dengan variasi bulanann sekitar 9\% [4].

Untuk intensitas cahaya matahari di daerah lokasi kegiatan sendiri tergolong bagus terlebih saat cuaca cerah, sehingga sangat dimungkinkan dilakukan pemasangan lampu penerangan jalan dan fasilitas umum dengan menggunakan energi surya. Pemasangan lampu tenaga surya dipilih karena dari segi dampak lingkungan tidak ada yang berdampak negatif, mudah, awet dan hemat. Dan lampu yang dipasang oleh tim P2M STT PLN juga memiliki sitem otomatis saat sekelilingnya tidak terdapat cahaya.

\section{METODE}

\subsection{Sifat dan Bentuk Kegiatan}

Skema dari Program Pengabdian Kepada Masyarakat dengan tema "Implementasi Teknologi Energi Surya Sebagai Wujud Mandiri Energi Di Masjid Al-Falah Serua Ciputat Tangerang Selatan" dilakukan ini adalah dengan tujuan untuk penerapan teknologi pembangkit listrik tenaga surya (PLTS ). Kegiatan tersebut akan dilaksanakan dengan melibatkan Institut Teknologi PLN dan masyarakat sekitar Masjid Al Falah Serua Ciputat Tangerang Selatan sebagai mitranya. Kegiatan utama dari pengabdian kepada masyarakat ini adalah berupa sosialisasi pengenalan tentang teknologi dari pembangkit listrik tenaga surya yang diimplementasikan dalam wujud lampu penerangan dan pelatihan tentang perakitan dan pemasangan dari lampu penerangan ini.

Untuk mencapai tujuan yang tercantum di atas, maka kami menempuh langkah-langkah sebagai berikut:

a. Menghubungi pemerintah daerah setempat untuk mendiskusikan topic program yang akan dilaksankan. Target luaran berupa dukungandari pemerintah daerah berupa penyediaan fasilitas tempat untuk sosialisasi dan pelatihan.

b. Menghubungi stakeholder yakni Pemda dan Pengurus Masjid Al Falah Serua Ciputat Tangerang Selatan untuk program kegiatan ini. Target luarannya berupa dukungan dari pengurus masjid dan stakeholder.

c. Sosialisasi kepada pengurus masjid dan juga warga sekitar masjid tentang pemanfaatan teknologi pembangkit listrik tenaga surya (PLTS) melalui sosialisasi. Sosialisasi yang diadakan bertema "Implementasi Teknologi Energi Surya Sebagai Wujud Mandiri Energi Listrik "yang dilaksanakan di Masjid Al-Falah Serua Ciputat Tangerang Selatan.

d. Untuk identifikasi komponen dan perakitan komponen peralatan diperlukan kurang lebih 3 bulan, sehingga di dapatkan suatu hasil yang sesuai dengan yang dibutuhkan oleh mitra. Identifikasi dan perakitan ini dilakukan di kampus Institut Teknologi PLN.

e. Pemasangan dari perangkat PLTS dalam bentuk lampu penerangan ini adalah merupakan tahap final dari kegiatan sosialisasi ini, dimana para peserta di perlihatkan perangkat PLTS dalam bentuk lampu penerangan dan pemasangan di lapangan untuk mewujudkan kemandirian energy listrik di Indonesia.

f. Selanjutnya dilakukan evaluasi dari kegiatan ini. Evaluasi ini dilakukan selama 1 bulan setelah pemasangan instalasi lampu penerangn PLTS dengan melihat keefektifan dari penggunaan lampu penrangan PLTS dan melalui quisioner kepada para peserta dengan 
harapan $40 \%$ dari total peserta yang hadir dapat menyerap dan menerapkan teknologi pembangkit listrik tenaga surya ini.

\subsection{Diagram Alir Kegiatan}

Diagram alir kegiatan dapat dilihat pada Gambar 2 berikut ini.

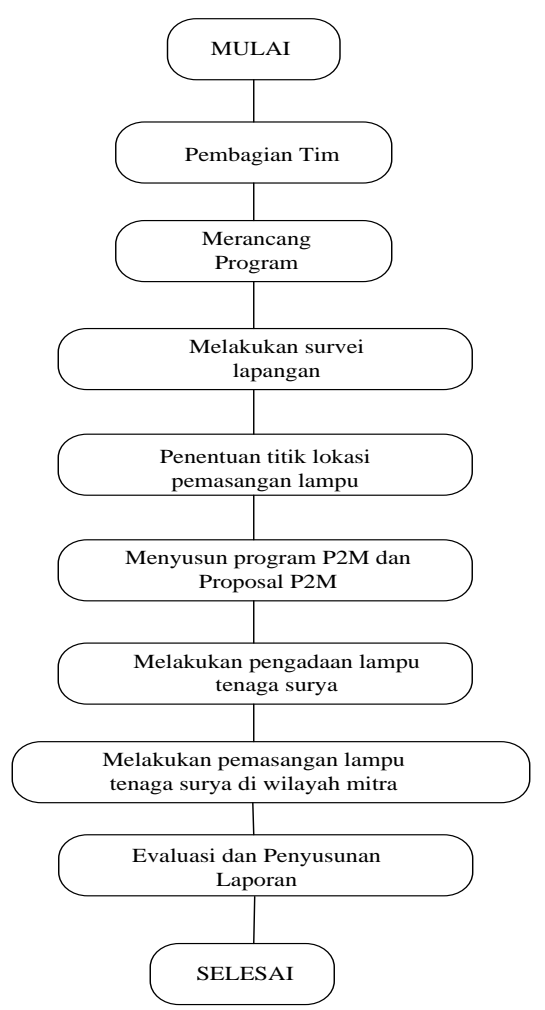

Gambar 3. Diagram Alir Kegiatan Pengabdian Kepada Masyarakat

\section{HASIL DAN PEMBAHASAN}

\subsection{Kegiatan Lapangan}

Lampu surya yang dipasang merupakan lampu 80 LED tenaga surya dengan baterai tertanam dengan daya lampu adalah 40 Watt dan sistem penyalaan otomatis. Tipenya adalah Lampu HILIOS SL-40 W Warna Light Putih. Lampu ini juga memiliki panel surya sebesar 40 watt. Lampu dilengkapi sensor cahaya yang dapat mendeteksi ada tidaknya cahaya. Sensor tersebut yang akan memicu penyalaan lampu otomatis jika cahaya di sekelilingnya gelap/ redup. Sebaliknya, lampu akan padam otomatis jika terdapat cahaya. Artinya lampu surya ini dapat menyala otomatis ketika matahari sudah terbenam dan dapat mati otomatis saat matahari terbit, selama berfungsi normal.

Berdasarkan uji coba sebelum pemasangan dengan keadaan baterai terisi penuh, lampu dapat menyala dengan cahaya maksimal selama kurang lebih 8 jam. Kemudian cahaya lampu akan semakin redup hingga lampu padam akibat kapasitas baterai kosong. Total waktu lampu dapat menyala adalah selama 12 jam. Jarak optimal penyinaran lampu ke tanah adalah 4 meter. Lebih dari itu, cahaya lampu kurang terang. Dari segi ketahanan, lampu ini memiliki ketahanan terhadap air hujan sehingga dapat diletakkan di luar ruangan (outdoor). Dimensi ukuran dari lampu ini yaitu $45 \mathrm{~cm} \mathrm{x} 20 \mathrm{~cm}$. Pemasangannya pun mudah karena lampu sudah dilengkapi dengan mur, baut, pelat besi, dan batang ekstensi lampu. Dengan demikian dapat ditarik kesimpulan bahwa lampu surya HILIOS SL-40W ini cukup baik untuk digunakan sebagai lampu penerangan di jalan-jalan kampung dan fasilitas umum. 


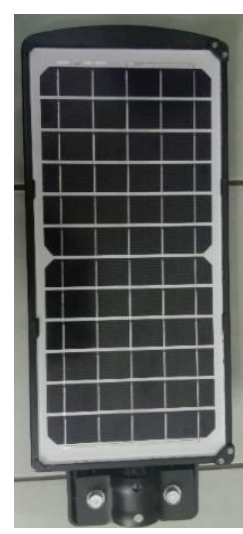

Gambar 4. Panel Lampu Surya HILIOS SL-40W

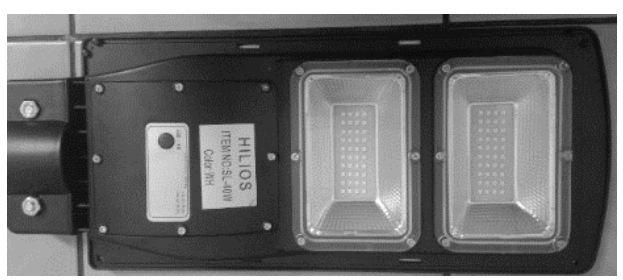

Gambar 5. LED Lampu HILIOS SL-40 W

Sebelum pemasangan lampu, tim PKM menyiapkan tiang lampu PJU berupa tiang besi hollow 6 meter. Dimana teknis penanaman tiang adalah 0,5 meter tertanam di dalam tanah. Tiap titik dipasang 1 tiang lampu dengan masing-masing tiang terpasang 1 buah lampu. Penanaman tiang lampu dan instalasi lampu pada tiang dibantu warga sekitar. Gambar 5 merupakan foto pembuatan tiang lampu yang akan di pasang di titik pemasangan.

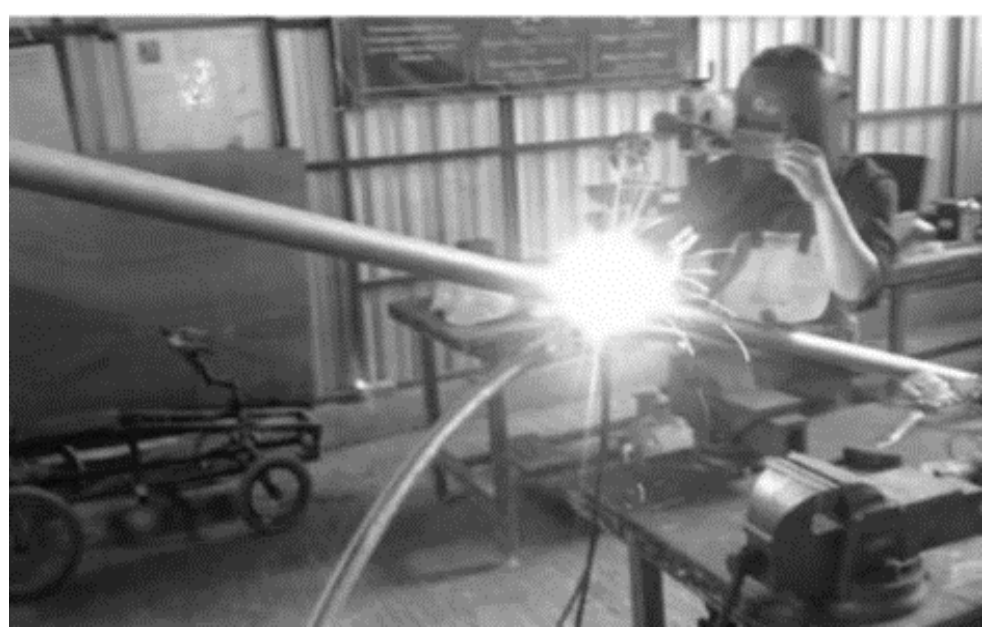

Gambar 6. Pembuatan Tiang untuk Lampu PJU

Selain melakukan pemasangan lampu, tim PKM juga melakukan penyuluhan kepada warga tentang lampu tenaga surya khususnya tentang cara kerja lampu dan penyelesaian ditemui masalah pada lampu tersebut. Warga sangat antusias dengan lampu surya yang dipasang, selain karena warga merasakan manfaat penerangannya, mereka juga tertarik dengan lampu surya tersebut karena ukurannya kecil dan pemasangannya relatif mudah dibanding lampu surya yang pernah mereka lihat. Gambar 5 menunjukkan warga yang mendengarkan penjelasan tim mengenai lampu tenaga surya. 


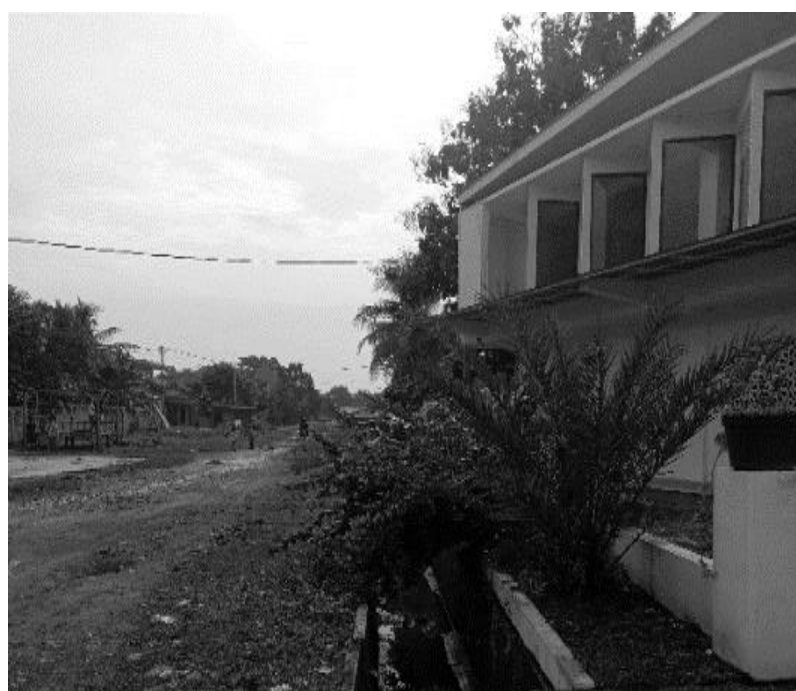

Gambar 7. Lokasi Sebelum di Pasang Lampu Tenaga Surya

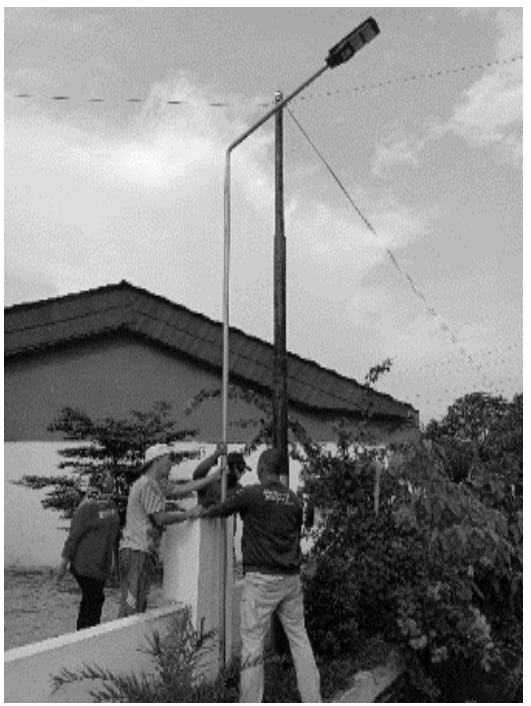

Gambar 8. Pemasangan lampu tenaga surya

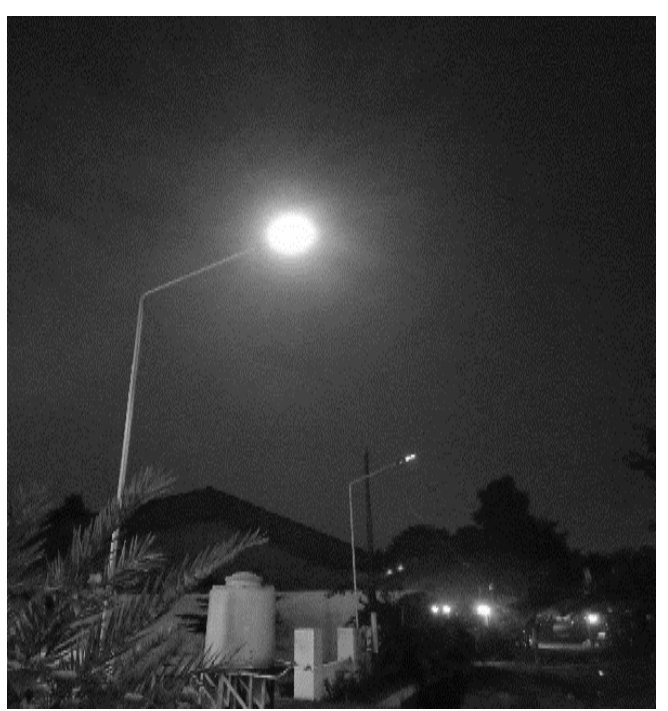

Gambar 9. Lokasi setelah di pasang lampu tenaga surya (malam hari) 
Lampu yang telah terpasang kemudian diamati pada saat malam hari, apakah dapat bekerja sesuai dengan prinsip kerjanya atau tidak. Yang meskipun kinerja lampu sebelumnya telah di uji coba terlebih dahulu. Anggota TIM secara langsung mengambil foto dan video kinerja dari lampu tenaga surya. Yang selanjutnya akan di lakukan evaluasi lanjutan. Selain foto keadaan lampu, tim PKM juga secara aktif memantau kinerja lampu dari hari kehari selama 3 hari. Warga juga diminta untuk menyampaikan keluhan dan masalah yang terjadi berkaitan dengan kinerja lampu surya. Sebagai antisipasi jika salah satu lampu tidak dapat berfungsi, tim PKM memberikan 2 buah lampu cadangan kepada warga. Jadi jika suatu saat lampu rusak, warga dapat menggantinya sendiri dengan lampu surya cadangan

Berdasarkan pengamatan warga, semua lampu surya dapat beroperasi dengan baik dan menyala otomatis. Penyinarannya juga cukup terang. Pada saat matahari terbit dan langit mulai terang, lampu secara otomatis dapat padam.

\subsection{Analisis Manfaat Ekonomi dari Lampu Tenaga Surya yang Dipasang}

Analisis keekonomisan pada lampu tenaga surya yang terpasang dilakukan untuk melihat manfaat dari sisi ekonomi dibandingkan dengan penggunaan lampu pijar untuk PJU. Lampu yang terpasang merupakan lampu pijar karena menurut warga lampu pijar lebih murah daripada lampu LED atau TL. Pada poin ini, akan dianalisis perbandingan dari sisi ekonomi terhadap PJU lampu surya dengan PJU lampu pijar untuk 1 titik lampu selama kurun 3 tahun

Pada tabel 1, dianalisis harga total yang harus dikeluarkan untuk pemakaian PJU lampu pijar, dengan asumsi lampu pijar memerlukan penggantian pada tahun ke 3 dengan harga lampu tetap. Karena lampu PJU memperoleh pasokan listrik dari rumah warga, maka biaya listrik yang diperlukan menyesuaikan Tarif Dasar Listrik untuk rumah tangga tahun 2019 yaitu sebesar Rp 1.467 dengan asumsi tidak ada kenaikan TDL selama 3 tahun ke depan. Jika lampu menyala selama 12 jam, maka kebutuhan listrik perhari adalah:

Lampu pijar $=40 \mathrm{Watt} \times 12 \mathrm{jam}=480 \mathrm{Wh}=0,48 \mathrm{KWh}$

Sedangkan selama 1 tahun, kebutuhan energi listrik untuk menghidupkan 1 lampu PJU adalah:

Wlampu pijar setahun $=0,48 \mathrm{KWh} \times 365$ hari $=175,2 \mathrm{KWh}$

Biaya listrik yang dikeluarkan selama 1 tahun adalah:

Biaya listrik setahun $=175,2 \mathrm{KWh} \times \mathrm{Rp} 1467=\mathrm{Rp} \cdot 257 \cdot 018,4$

Tabel 1. Analisis Biaya Penggunaan PJU Lampu Pijar

\begin{tabular}{|l|c|c|c|}
\hline \multicolumn{1}{|c|}{ Pengeluaran } & $\begin{array}{c}\text { Tahun ke-1 } \\
(\mathbf{R p})\end{array}$ & $\begin{array}{c}\text { Tahun ke-2 } \\
(\mathbf{R p})\end{array}$ & $\begin{array}{c}\text { Tahun ke-3 } \\
(\mathbf{R p})\end{array}$ \\
\hline Lampu pijar 40 Watt & $30.000,00$ & 0 & $30.000,00$ \\
\hline Tiang besi & $300.000,00$ & 0 & 0 \\
\hline Kap lampu & $30.000,00$ & 0 & 0 \\
\hline Kabel AWG22x2 8 meter & $50.000,00$ & 0 & 0 \\
\hline Biaya listrik 1 tahun & $257.018,4$ & $257.018,4$ & $257.018,4$ \\
\hline \hline Total (pertahun) & $\mathbf{6 6 7 . 0 1 8 , 4}$ & $\mathbf{2 5 7 . 0 1 8 , 4}$ & $\mathbf{2 8 7 . 0 1 8 , 4}$ \\
\hline TOTAL BIAYA (3 tahun) & Rp $1.211 .055,2$ & \multicolumn{3}{|l}{} \\
\hline
\end{tabular}

Pada tabel 3, dianalisis harga total yang harus dikeluarkan untuk pemakaian PJU lampu tenaga surya. Berdasarkan data sheet lampu, lampu PJU LED tenaga surya dapat digunakan selama 50.000 jam $=5,7$ tahun sebelum akhirnya lampu akan rusak. Sehingga, tidak diperlukan biaya penggantian 
lampu tenaga surya jika analisis yang dilakukan selama jangka waktu 3 tahun. Agar penyinaran PJU optimal, maka setiap tiang lampu terpasang 1 buah lampu tenaga surya.

Tabel 2. Analisis Biaya Penggunaan PJU Lampu Tenaga Surya

\begin{tabular}{|l|c|c|c|}
\hline \multicolumn{1}{|c|}{ Pengeluaran } & $\begin{array}{c}\text { Tahun ke-1 } \\
(\mathbf{R p})\end{array}$ & $\begin{array}{c}\text { Tahun ke-2 } \\
(\mathbf{R p})\end{array}$ & $\begin{array}{c}\text { Tahun ke-3 } \\
(\mathbf{R p})\end{array}$ \\
\hline Lampu HILIOS SL-40W & $600.000,00$ & 0 & 0 \\
\hline Tiang besi & $300.000,00$ & 0 & 0 \\
\hline Total (pertahun) & $\mathbf{9 0 0 . 0 0 0 , 0 0}$ & $\mathbf{0}$ & $\mathbf{0}$ \\
\hline TOTAL BIAYA (3 tahun) & \multicolumn{3}{|c|}{ Rp 900.000,00 } \\
\hline
\end{tabular}

Berdasarkan hasil analisis pada tabel 1 dan 2, diperoleh perbedaan total biaya yang besar untuk pengoperasian kedua PJU selama 3 tahun. Untuk pengoperasian PJU lampu pijar selama 3 tahun, diperlukan biaya sebesar Rp 1.211.055,2. Sedangkan PJU lampu surya hanya memerlukan biaya Rp 900.000,00. Walaupun harga lampu PJU tenaga surya lebih mahal, tetapi untuk penggunaan jangka panjang, PJU lampu tenaga surya jauh lebih ekonomis dibandingkan PJU lampu pijar, dengan selisih biayanya adalah sebesar Rp 311.055,2 untuk jangka waktu 3 tahun. Sementara untuk lampu PJU tenaga surya memiliki daya hidup selama 5,7 tahun dan tidak dipengaruhi oleh adanya kenaikan TDL (tarif dasar listrik).

\section{KESIMPULAN}

Kegiatan Program Kemitraan Masyarakat (PKM) mengenai Pemanfaatan Energi Surya untuk Penerangan Jalan \& Fasilitas Umum di Masjid Al Falah Serua Ciputat Tangerang Selatan telah berhasil dilaksanakan pada tanggal 08 Juni 2020. Kegiatan tersebut berupa pemasangan lampu Penerangan Jalan Umum (PJU) dengan memanfaatkan tenaga surya. Lampu yang digunakan adalah lampu merk HILIOS SL-40 W. Pada bagian atas lampu terdapat panel surya sebesar 40 Watt. Lampu juga memiliki sistem penyalaan otomatis dengan mendeteksi cahaya sekitar dan baterai tertanam sebesar $2000 \mathrm{mAh}$. Sebelum lampu tersebut dipasang, tim PKM melakukan survei lapangan untuk menentukan titik-titik pemasangan lampu. Diperoleh 3 titik pemasangan lampu yang strategis yaitu di jalan kampung menuju masjid dan di masjid Al Falah itu sendiri.

Pemasangan lampu telah berhasil dilakukan. Lampu dapat beroperasi dengan baik pada malam hari. Analisis kinerja lampu tenaga surya juga ditinjau dari segi ekonomi dengan cara membandingkan total pengeluaran yang diperlukan untuk lampu PJU tenaga surya dan PJU yang menggunakan lampu pijar dengan sumber listrik dari rumah warga. Berdasarkan hasil perhitungan, pengoperasian PJU lampu pijar selama 3 tahun, memerlukan biaya sebesar Rp 1.211.055,2. Sedangkan PJU lampu surya hanya memerlukan biaya Rp 900.000,00. Sebagian biaya PJU lampu pijar digunakan untuk membayar biaya listrik.

Walaupun harga lampu PJU tenaga surya lebih mahal, tetapi untuk penggunaan jangka panjang, PJU lampu tenaga surya jauh lebih ekonomis dibandingkan PJU lampu pijar, dengan selisih biayanya sebesar Rp 311.055,2 untuk pemakaian jangka waktu 3 tahun. Sementara usia hidup nyala dari lampu PJU tenaga surya bisa mencapai 5,7 tahun, sehingga bila di analisis untuk ke ekonomisan dari lampu PJU tenga surya dan dibandingkan dengan biaya lampu PJU pijar akan sangat terlihat perbedaannya. Dengan catatan adanya pemeliharaan dan perawatan yang baik pada lampu PJU tenaga surya dan tidak tertutup oleh dahan ranting dan sebagainya. Sehingga daya tangkap dari panel surya semakin baik. 


\section{SARAN}

Saran yang dapat diberikan untuk program pengabdian kepada masyarakat ini adalah pemasangan lampu PJU tenaga surya dengan titik-titik pemasangan yang lebih luas sehingga warga desa dapat mandiri energy listrik dari pasokan jaringan PLN.

\section{UCAPAN TERIMA KASIH}

Penulis mengucapkan terima kasih kepada Institut Teknologi PLN Jakarta dan LPPM atas kesempatan kepada tim PKM dan dukungan baik moril maupun materiil serta pendanaan sehingga kegiatan PKM dapat terlaksana dengan baik.

\section{DAFTAR PUSTAKA}

[1] DISEMINASI RUPTL 3019-3028 PT PLN (Persero) Keputusan Menteri ESDM No. 39K/30/MEM/3019.

[2] Jaelani,A,3017.Energi Baru Terbarukan Di Indonesia: Isyarat Ilmiah Al Quran Dan Implementasinya Dalam Ekonomi Islam.University Library of Munich,Jerman.

[3] Manan,Saiful.3009.Energi Matahari, Sumber Energi Alternatif Yang Efisien,Handal dan Ramah Lingkungan di Indonesia.Gema Teknologi.

[4] Widayana,G.3012.Pemanfaatan Energi Surya Jurnal Pendidikan dan Teknologi dan Kejuruan,9(1)

[5] http://djk.esdm.go.id/pdf/RUPTL/3019\%3003\%3018\%30Diseminasi\%30RUPTL\%3030193028.pdf

[6] http://www.panelsurya.com/index.php/id/panel-surya-solar-cells/560-pembangkit-listriktenaga-surya-energi-terbarukan 